\title{
The Rights of Nature: Reconsidered
}

\section{PETER BURDON}

\begin{abstract}
When God-like Odysseus returned from the wars in Troy, he hanged all on one rope a dozen slave-girls of his household whom he suspected of misbehaviour during his absence. This hanging involved no question of propriety. The girls were property. The disposal of property was then, as now, a matter of expediency, not of right and wrong. (Leopold 237)
\end{abstract}

In 1972, Professor Christopher Stone from the University of Southern California was approaching the final minutes of an introductory lecture on property law. He noted that, like human culture, property law is an evolving social construct and has progressed through different stages of growth and development (Schlatter). As Aldo Leopold notes in the introductory quote, human beings were once considered property. Assault or even the intentional killing of a slave was considered a matter for property law, not a matter for human rights. Throughout history, we have seen a continual evolution in the types of things that can be owned, who was considered capable of ownership and the meaning of ownership itself (Stone, 'Trees' vii). Stone commented to his class that it was easy to see how each change shifted the locus and quality of power ... each advance in the law-legitimated concept of "ownership", fuelling a change in consciousness, in the range and depth of feelings' ('Trees' vii). Stone was awakened from this historical narrative by the shuffling and voices of his students who had begun to 'pack away their enthusiasm for the next venture' ('Trees' vii). In an effort to maintain their attention, he wondered aloud:

So, what would a radically different law-driven consciousness look like?

... One in which Nature had rights ... Yes, rivers, lakes ... trees ... animals

... How would such a posture in law affect a community's view of itself?

('Trees' vii)

This thought experiment created uproar and as Stone stepped out of the lecture theatre he asked himself, 'what did you just say in there? How could trees have rights?' ('Trees' vii). Evidently, he had no idea. Thirty years later, Stone's paper 'Should Trees Have Standing' and its influence in Sierra Club $v$ 
Morton ${ }^{1}$ has become the thing of legend and continues to resonate with pockets of students in contemporary law schools. However, until recently, the notion of recognising nature as an entity capable of holding rights was completely ignored by lawmakers. ${ }^{2}$ Writing in the American Bar Association Journal in 1973, practising lawyer John Naff captures the profession's early reactions to Stone's thesis and the dissenting judgement of Justice Douglas in Sierra Club. He writes:
If Justice Douglas has his way -
O Come not that dreadful day -
We'll be sued by lakes and hills
Seeking a redress of ills
Great Mountain peaks of name prestigious
Will suddenly become litigious
Our brooks will babble in the courts,
Seeking damages for torts
How can I rest beneath a tree
If it may soon be suing me?
Or enjoy the playful porpoise
While it's seeking habeas Corpus?
Every beast within his paws
Will clutch an order to show cause
The Courts besieged on every hand,
Will Crowd with suits by chunks of land.

Ah! But vengeance will be sweet

Since this must be a two-way street.

I'll promptly sue my neighbour's tree

For shedding all its leaves on me. (727)

That Naff chose to write in comical verse is instructive. Indeed, while the law had recently shifted to recognise racial and gender equality, ${ }^{3}$ it was not yet ready to consider seriously an extension of rights to nature. Stone anticipated this resistance, noting '[t]hroughout legal history, each successive extension of

\footnotetext{
1 Stone's thesis concerned the legal issue of standing. Here the court affirmed the existing test that required the party seeking review to have suffered actual damage. However, in a dissenting judgement, Justice Douglas noted "the critical question of "standing" would be simplified and also put neatly in focus if we ... allowed environmental issues to be litigated ... in the name of the inanimate object about to be despoiled, defaced, or invaded. ... Contemporary public concern for protecting nature's ecological equilibrium should lead to the conferral of standing upon environmental objects to sue for their own preservation ... this suit would therefore be more properly labelled as Mineral King v. Morton' (See Should Trees Have Standing?). Both Justices Blackmum and Brennan favoured the conventional interpretation of standing but in the alternative would have permitted the 'imaginative expansion' of standing advocated by Stone and Douglas.

2 For an interesting survey see Stone, 'Do Morals Matter?'. Stone notes: 'Right! / 2 (nature of environment) ... gets 192 hits in the ALLFEDS database, even though one might have expected courts to be the more hospitable forum for rights-talk. None of the $10 \%$ samples was philosophically significant'.

3 Specifically in regard to the civil rights and feminist movements.
} 
rights to some new entity has been, thereto, a bit unthinkable ... each time there is a movement to confer rights onto some new "entity", the proposal is bound to sound odd or frightening or laughable' ('Trees' 2-3). This is because until the entity in question is recognised as having rights, 'we cannot see it as anything but a thing for the use of 'us' - those who are holding rights at the time' ('Trees' 3). This is true for nature, as it was for slaves, women and children at different points in history.

Three decades later, lawmakers are beginning to take seriously Stone's thesis as a novel and potentially powerful means to protect the environment. In part one of this article, I will detail how the rights of nature have been recognised in municipal ordinances in the United States, the Constitution of Ecuador and in a proposed United Nations Declaration. Following this, I will outline pertinent philosophical objections to the concept of rights and where possible, consider responses to these objections. I contend that the current environmental rights movement must engage seriously with the extensive literature on rights and advocate a position which is robust and intellectually sound. If this can be achieved, recognising the rights of nature could represent a powerful tool for environmental protection and place appropriate responsibilities on human beings as members of a broader Earth community.

\section{The Circle Expands}

\section{Municipal Law: The United States}

The Community Environmental Legal Defense Fund (CELDF) is a not-for-profit environmental office, founded in 1995 in the State of Pennsylvania, USA. ${ }^{4}$ Their principle clients are conservative, rural farming communities who have sought assistance to stop the production of incinerators, factory hog farms and other large-scale projects (Margil 1). After many years of conventional environmental practice, CELDF grew despondent and sceptical of the mainstream framework for environmental protection. Associate Director Mari Margil explains:

What our experience showed us was that our system of environmental laws and regulations don't actually protect the environment. At best, they merely slow the rate of its destruction. After several years, we stopped doing that work. We weren't helping anyone protect anything. (1)

The practice of environmental law seeks to protect the environment by 'regulating' human interaction. Only in exceptional circumstances are communities provided the legal right to say no to an activity or stop an existing project. Of course, many activities, such as logging old growth forest and

4 See $<$ http://www.celdf.org.au $>$ 
mineral extraction cause considerable harm to the environment. However, unless a human or representative body can demonstrate direct harm as a result of the activity, they cannot meet the requirement of standing to challenge the action. In light of this limitation, the vast majority of work carried out by environmental organisations is to make sure a proponent is meeting their agreed obligations and has applied for the appropriate licenses. Director of CELDF Thomas Linzey provides an example of this work. In his first years in practice he would appear before an administrative judge to argue over a permit application. He would argue, 'Your honor, this permit is missing what's required by 26 CFR, Section little 2, little c, little $\mathrm{i}$, little a, little $2 \mathrm{~d}^{\prime}$. Commonly, the judge would respond 'You're absolutely right. Little 2, little c, little 2, little d, little 2, little a is missing from this application ... I'm going to throw the permit out because it's not complete' (Linzey, 'Of Corporations'). Following the ruling the community group would invite the lawyers back to their home for a victory party. However, in just a short time the proponent would resubmit a stronger application, with the identified gaps filled. The community group would again appeal to CELDF for assistance but all potential appeal grounds had been exhausted and in just a short time the project was constructed. Linzey notes, 'This story was repeated more times than I care to remember' ('Of Corporations').

Reflecting on the orthodox framework for environmental protection, Linzey comments, 'the only thing that environmental regulations regulate are environmentalists' ('Of Corporations'). Indeed, once an activity has gained the imprimatur of law it is very hard to stop. Those seeking to protect the environment are channelled into an established framework with predefined boundaries and response mechanisms. Operating solely within these bounds has made environmental regulation predictable and reduced its effectiveness. Indeed, by every measurable statistic, the environment is in a worse condition today than thirty years ago when the first environmental protection law was passed. ${ }^{5}$ Adding salt to the wound, Linzey notes that it is common practice for companies involved in controversial projects to set aside money to fight anticipated permit challenges. He notes, 'It's a cost of doing business, not only is it a cost of doing business, it's tax deductible!' ('Of Corporations'). Faced with this understanding, the practitioners at CELDF were forced to think outside the limits of conventional environmental practice and ask: how can we best protect the environment?

In 2006, residents from the rural township of Blaine engaged the services of CELDF to help them oppose the expansion of coal mining into their community. Coal companies purchased the rights to the 'Pittsburgh coal seam' ${ }^{6} 250$ years

5 For example, see <http://www.millenniumassessment.org/>. For updated information see World Watch Institute, <http://worldwatch.org $>$ and Brown, Plan 4:0.

6 Common name of the coal deposit in the region. 
ago, and have been extracting from surrounding regions since this period. While once a slow and tedious process, modern extraction occurs through a process called 'long-wall mining'. Linzey explains:

Six to eight hundred feet below the earth's surface, depending on the seam, a machine moves across the face of the coal, grinding it up at tremendous speed. After the machines come through and remove the coal, the earth drops three to six feet above the seam. This is called subsidence. ('Be the Change' 25)

Because of the damage this process causes to soil structure and subterranean ecosystems, it has been banned in many countries, including Germany where it originated ('Be the Change' 25). With the assistance of CELDF, the Blaine community collectively drafted ordnance that sought to ban corporations from mining in their area, recognise the rights of ecosystems and strip corporations of their power to override the ordinances. At the conclusion of this process, the ordinance was advertised and a time was set for public comment. Only two people spoke against the ordinance, 'a representative from the coal company and an attorney, who threatened the supervisors with law suits' ('Be the Change' 37). While much more could be said, the section relating to the rights of nature provides that ecosystems - including wetlands, rivers, and streams, 'possess inalienable and fundamental rights to exist and flourish within the Township of Blaine' (Margil 3). The people of Blaine had the ability to defend the rights of ecosystems without having to prove standing, and damages were to be measured by harm caused to the ecosystem itself.

Following this ordinance, CELDF have worked with over 200 communities and over 20 have adopted rights for nature ordinances. One example is Barnstead New Hampshire, who adopted their ordinance in 2008 by a vote of 135 to 1 . The ordinance confers rights on specific parts of nature and reads:

Natural communities and ecosystems possess inalienable and fundamental rights to exist and flourish within the Town of Barnstead. Ecosystems shall include, but not be limited to, wetlands, streams, rivers, aquifers, and other water systems. (Margil 3)

More recently CELDF has worked with the city of Spokane, Washington, ${ }^{7}$ and Pittsburgh, Pennsylvania. Both cities represent a combined population of over 500,000 people. While one does not commonly associate rural American townships as a source of progressive environmental ethics, their vision and earnest desire to protect local ecosystems represents a tangible fulfilment of

7 For further information see $<$ http://envisionspokane.org/index.html $>$. 
Stone's thesis for recognising the rights of nature. ${ }^{8}$ However, it must be noted that municipal ordinances are the most grass-roots form of law and subservient to the laws of the state and the constitution. In the event of inconsistency with these 'higher' laws, the ordinances can be struck down. ${ }^{9}$ To secure the rights of nature, one needs to implement change further up the legal hierarchy.

\section{Constitutional Law: Ecuador}

The legal developments in the United States quickly attracted international attention from organisations and governments looking to strengthen environmental safeguards. One such organisation was the Pachamama Alliance, a not-for-profit environmental office operating in San Francisco and Ecuador. In 2007, Ecuador began the process of drafting a new constitution and the Pachamama Alliance had begun a dialogue with the Ecuadorian government about including provisions that would better protect the environment. Like many other third world countries, Ecuador has been used as a dumping ground for many wealthy western corporations, who exploit weaker safety and environmental standards. This culminated when Texaco (subsidiary of Chevron) dumped nearly 16 million gallons of oil and 20 billion gallons of waste into 17,000 acres of pristine forest. In addition to the environmental impacts, local indigenous groups have claimed that the dumping has resulted in higher rates of cancer and miscarriages (Mayhew 8-9).

The Pachamama Alliance invited representatives from CELDF to meet with delegates from the Ecuadorian Constitutional Assembly, including former minster of energy, Alberto Acosta. Margil recalls:

We thought that we'd have an uphill battle trying to explain to this former minister of energy and mines why communities in the U.S. were adopting laws recognizing ecosystem rights. But before we had a chance to say anything, he told us that to his mind, the law treats nature as a slave, with no rights of its own. We had found a meeting of the minds in one of the most unlikely, but most critical of places. (4)

Acosta requested that CELDF draft a constitutional provision for them to consider. This was shaped and expanded by the Constitutional Assembly. In September 2008, an overwhelming majority of citizens approved the new constitution and Ecuador became the first country in the world to codify the rights of nature in their constitution. The provisions relating to the rights of nature read:

8 In making this point I acknowledge that many farmers and farming communities have intimate connection with the land and possess a strong conservation ethic.

9 As this article was being finalised, the township of Blaine had their ordinances declared invalid and longreach coal mining has been introduced into the area. 
Art. 1: Nature or Pachamama, where life is reproduced and exists, has the right to exist, persist, maintain and regenerate its vital cycles, structure, functions and its processes in evolution. Every person, people, community or nationality, will be able to demand the recognitions of rights for nature before the public organisms. The application and interpretation of these rights will follow the related principles established in the Constitution.

Article 2: Nature has the right to an integral restoration. This integral restoration is independent of the obligation on natural and juridical persons or the State to indemnify the people and the collectives that depend on the natural system. In the cases of severe or permanent environment impact, including the ones caused by the exploitation of non-renewable natural resources, the State will establish the most efficient mechanisms for the restoration, and will adopt the adequate measures to eliminate or mitigate the harmful environmental consequences.

Article 3: The State will motivate natural and juridical persons as well as collectives to protect nature; it will promote respect towards all the elements that form an ecosystem. (Linzey, 'Be the Change' 134-135)

It is important to note that in contrast to the United States Municipal Ordinances, this provision leaves nature undefined. The use of general language is common in constitutional drafting and allows for words to have broad interpretation and remain relevant over time. However, it also provides no guidance for lawmakers or those who would seek to enforce nature's rights. As a result, questions remain regarding how this article will be integrated with other legislation and provide a comprehensive scheme for environmental protection. Further to this practical point is the question of how President Correa's government will interpret and uphold this provision in the face of industry and social pressure to combat competing issues such as poverty and unemployment.

\section{International Law: Charter for Mother Earth Rights}

Following their South American neighbours, on the 22 April 2009, Bolivian President Evo Morales Ayma addressed the United Nations General Assembly and articulated his hope that the twenty-first century would be known as the century of the rights of Mother Earth. To achieve this hope, Morales called on member states to develop a Declaration on the Rights of Mother Earth which, among other things 'would enshrine the right to life for all living things; the right for Mother Earth to live free of contamination and pollution; and the right to harmony and balance among and between all things' (Cullinan, 'A History' 4). This was followed on 17 October 2009 by a declaration from the Bolivarian 
Alliance for the Peoples of Our America supporting the call for the adoption of a Universal Declaration of Mother Earth Rights. The Declaration expresses the fundamental tenets of Berry's Proposal with great clarity, stating:

In the 21st century, it is impossible to achieve full human rights protection if at the same time we do not recognise and defend the rights of the planet earth and nature. Only by guaranteeing the rights of Mother Earth can we guarantee the protection of human rights. The planet Earth can exist without human life, but humans cannot exist without planet Earth. (Cullinan, 'A History' 4)

On 22 April 2010, Bolivia hosted a Peoples' World Conference on Climate Change and Mother Earth Rights. ${ }^{10}$ The conference was attended by over 35,000 people and concluded with President Morales adopting a declaration which will be presented to the United Nations. The declaration draws inspiration from other authoritative agreements such as the Universal Declaration of Human Rights and the Earth Charter. The preamble expressly acknowledges our profound dependence and relationship with the Earth, noting 'we are all part of Mother Earth, an indivisible, living community of interrelated and interdependent beings with a common destiny' (People's Conference). Specifically in regard to rights, the declaration states:

Article 2. Inherent Rights of Mother Earth

(1) Mother Earth and all beings of which she is composed have the following inherent rights:

(a) the right to life and to exist;

(b) the right to be respected;

(c) the right to continue their vital cycles and processes free from human disruptions;

(d) the right to maintain its identity and integrity as a distinct, self-regulating and interrelated being;

(e) the right to water as a source of life;

(f) the right to clean air;

(g) the right to integral health;

(h) the right to be free from contamination, pollution and toxic or radioactive waste;

10 See $<$ http://motherearthrights.org $>$. 
(i) the right to not have its genetic structure modified or disrupted in a manner that threatens its integrity or vital and healthy functioning;

(j) the right to full and prompt restoration for the violation of the rights recognized in this declaration caused by human activities;

(2) Each being has the right to a place and to play its role in Mother Earth for her harmonious functioning.

(3) Every being has the right to wellbeing and to live free from torture or cruel treatment by human beings.

(People's Conference )

The declaration is not limited to ecosystems and expressly includes non-human animals. For example article one, part five notes that 'Mother Earth and all beings are entitled to all the inherent rights recognised in this Declaration without distinction of any kind, such as may be made between organic and inorganic beings, species, origin, use to human beings of any other states' (People's Conference ). Further, the declaration notes in part six 'just as human beings have human rights, all other beings have rights which are specific to their species or kind and appropriate for their role and function within the communities within which they exist' (People's Conference). Finally, the declaration places specific obligations on human beings in regard to their interaction with nature. For example, article three, part one, notes that human beings are responsible 'for respecting and living in harmony with Mother Earth'. Further obligations listed in part two include to 'promote the full implementation and enforcement of the rights'; 'promote and participate in learning, analysis, interpretation and communication about how to live in harmony with Mother Earth'; 'ensure that the damages caused by human violations ... are rectified and that those responsible are held accountable for restoring the integrity and health of Mother Earth' and 'empower human beings and institutions to defend the rights of Mother Earth' (People's Conference ).

\section{Rights: A Troublesome Concept}

That the concept of rights that has worked so well to protect human dignity is a hallmark of recent cultural progress. The rights model, however, proves troublesome when used to protect the biological world. (Rolston 256)

From a legal-operational perspective the notion of recognising the inherent rights of nature is relatively straightforward (Stone, 'Trees' 4-23). Courts can look directly at the harm caused to nature; the legal concepts, standing and 
guardianship, can be extended to provide local communities, environmental NGO's or traditional owners with the power to speak on behalf of the entity; and compensation can be awarded in its favour. Certainly, the legal tools required to implement this system already exist and as noted above, are being implemented to suit this purpose. Yet, law is only as good and effective as the intellectual foundations that underpin it. While many individuals are attracted to the rhetoric and potential of a rights-based environmental movement, it is vital to pause and reflect on the philosophical objections and extensive literature surrounding this debate. This section will highlight and, where possible, respond to some of the hard questions involved in expanding rights beyond human beings. Having considered this aspect, we will be in a stronger position to consider its desirability as a tool for environmental protection.

\section{Legal Categories}

The first significant objection is from environmental philosopher Holmes Rolston III. Rolston correctly notes that the language and framework of rights is a uniquely human construct. There were no rights for the billions of years prior to human beings and outside of our community, there are no rights today (Rolston 256). Trees, rivers, mountains and soil do not have rights and they are unable to recognise the rights of others. Thus, a mountain slide that uproots a small pine forest does not violate the rights of the tree community. Even if the mountain slide kills human beings, it does not violate human rights. The mountain is not guilty of reprehensible behaviour and one cannot bring it to be shamed in a court of law. Legal rights correspond with legitimate claims and entitlements. Thus, a mountain climber has a right to be rescued by a mountain ranger, because of their relationship and the existence of a duty of care. If the mountain ranger stood and watched the mountain slide engulf the mountain climber and he was in a reasonable position to rescue the individual, he would be morally, as well as legally, responsible. Reflecting on this point, Rolston notes: 'Using the language of rights for rocks, rivers, plants and animals is comical, because the concept of rights is an inappropriate category for nature' (257).

An intellectually sound rights-based discourse must acknowledge and accept Rolston's comments. It is plainly nonsense to speak of nature holding duties or to suppose that rights exist between one part of nature and another. The concept applies only in the context of human interaction with nature and would place duties only on human beings. Importantly, Stone foresaw this objection in Trees, commenting:

to say that the environment should have rights is not to say that it should have every right we can imagine, or even the same body of rights as human beings have. Nor is it to say that everything in the environment should have the same rights as every other thing in the environment. (4) 
Rather than simply transplanting the full range of rights held by human beings onto other entities, one can implement the concept in a limited and relative fashion. The recognition of rights is not an 'all or nothing' conferral. Commenting on this point, Thomas Berry notes, 'rights in the nonliving form are role-specific; rights in the living form are species specific and limited' ('Evening Thoughts' 111). Thus, rivers have river rights; trees have tree rights; birds have bird rights and humans have human rights. The difference is qualitative, not quantitative, and the rights of one part of nature would be of no value to another part. Finally, it should be noted that this specific application of rights requires an intimate understanding of the entity in question and a precise determination of the borders/constituents of an ecosystem or species. Potential power dynamics arise regarding 'who speaks for nature' and in particular the role of science in answering these questions. For a rights-based environmental movement to be taken seriously in western culture, disciplines such as ecology will need to play a primary role. Ideally however, traditional owners and local communities would have input into this process and could supplement the general principles of science with specific, place-based knowledge and natural history.

\section{In Nature's Interest?}

The only stone which could be of moral concern and hence deserving of legal rights is one like Christopher. (Elder 285)

The proceeding section gives rise to two further questions: does nature have interests? And if so, how can people accurately discern what those interests are? Mark Sagoff powerfully raised the first objection in 1974 in response to Stone's thesis. Sagoff mocked the idea that 'all of nature marches forward in legal equality, with rights for all, without regard to race, creed, color, sex, leaf structure, or atomic number' ('On Preserving' 221). How, he wondered, did Stone or the environment movement purport to know the interests of a voiceless object? Turning to the facts under examination in Trees, Sagoff asked: 'Why wouldn't Mineral King [mountain] want to host a ski resort, after doing nothing for a billion years?' ('On Preserving' 222). In making this statement Sagoff is not siding with development. However, by turning the issue around, he highlights the inherent difficulty of discerning the interests of nature and also the presumption that conservation, not development represents this interest. If a presumption or individual case is decided in favour of conservation, this will need to be justified and considered with reference to the needs of other parts of nature, such as human beings. ${ }^{11}$

Returning to the important issue of 'interest', the current debate is influenced heavily by Joel Feinberg and his 'interest principle'. Briefly, Feinberg considered

11 See further Sagoff, 'Do Non-Native Species Threaten the Natural Environment'. 
that an entity could possess rights if it had the ability to be harmed or benefited and was conscious of such treatment. Feinberg notes, 'without awareness, expectation of belief, desire, aim and purpose, a being can have no interest; without interests, he cannot be benefited; without the capacity to be benefited, he can have no rights' (47). This principle restricts the category of potential right-holders to people and most nonhuman animals. In regard to the latter, Feinberg argued that they were not moral agents but possess interests and thus a right to have these interests respected. Plants, rivers, mountains and forests were excluded from Feinberg's rights community on the basis that they possess insufficient 'cognitive equipment' to possess interests, needs or wants (50). Even less deserving of rights were what Feinberg terms 'things'. He notes, '[i]t is absurd to say that rocks can have rights ... because rocks belong to a category of entities of whom rights cannot be meaningfully predicated' (60). People can still enact laws for environmental protection, however; these laws should be understood as a category of human interest and of human rights to benefit from nature.

One response to Feinberg's interest principle is the development of holistic philosophy, common to followers of Alfred North Whitehead, Gaia theory and Deep Ecology. From this perspective, everything in nature, down to the cells and atoms, has the potential for fulfilment. Berry exemplifies this view in the following statement:

In reality there is a single integral community of the Earth that includes all its component members whether human or other than human. In this community every being has its own role to fulfil, its own dignity, its inner spontaneity. Every being has its own voice. Every being declares itself to the entire universe. Every being enters into communion with other beings. This capacity for relatedness, for presence to other beings, for spontaneity in action, is a capacity possessed by every mode of being throughout the universe. ('Great Work' 4)

Further to this point, one should be hesitant to draw moral boundaries on the basis of cognitive ability or the extent to which an entity can be described as an 'honouree human'. Descartes famously excluded animals from the moral community on the same basis as Feinberg denies other parts of nature.

Stone also responded to this objection and advanced the notion of 'moral pluralism' as the means to include 'unorthodox entities' which lack discernable interests in ethical and judicial systems. Stone notes that ethical activity exists on several different levels. To illustrate this point he draws an analogy with maps that reveal different information about the same area and serve distinct purposes. He notes, '[t]here is no one map that is right for all the things we want to do with maps ... nor is one map more right than another' ('Ethics' 137- 
42). Following from this analogy, Stone envisioned different ethical systems that could regulate human behaviour toward each other, different levels within the environment and also other things such as embryos and clones. As a starting point, Stone suggested a presumption that all objects (and parts/qualities of objects) held legalconsiderateness ('Ethics' 44-62). With reference to nature, this presumption rests on the idea that a river has value in its whole condition 'simply because the universe is better for containing it in that state' ('Ethics' 59). Thus, if a specified condition of a lake is harmed, its guardians could represent its 'rights' in court and seek redress or compensation on its behalf. As Roderick Nash notes, 'in effect this was a backdoor way of giving [nature] legal rights without using either human interests or a supposition of the existence of interests on the part of the lake' (135).

\section{Human Domestication}

Following from this point, John Livingston questions whether or not recognising the rights of nature would actually achieve environmental protection. Instead, he notes that the consequence of the recognition would be to domesticate nature. In a recent interview he noted:

I don't think I want a redwood grove to have rights. Rights are political instruments - legal tools. We hear a lot of talk about 'extending' rights to nature. How bloody patronizing! How patriarchal for that matter. How imperialistic. To extend or bestow or recognise rights in nature would be, in effect, to domesticate all of nature - to subsume it into the human political apparatus. ('Listening' 62)

Part of Livingston's point is that if lawmakers were to enact a general provision stating that nature has rights, the legal framework could be imported across all of nature. While this might be attractive at first blush, Livingston warns that it 'represents the dedication of the entire planet to the human organization, the final conquest of Nature' ('Rogue Primate' 173). Indeed, taken to its extreme, environmental rights would result in the humanisation of wild forests and grasslands and even the deepest parts of the ocean. Further, Livingstone notes that the framework of rights is a poor reflection of how 'natural' relationships function. Livingston notes, 'to suggest that our dogs have a right to demand our company and we have the duty to provide it, is to perceive our relationship as a political one, based on power and dominance, submission and subservience' ('Rogue Primate' 161).

While not wishing to dismiss Livingston's objection, it should be noted that the municipal ordinances passed in the United States are specific and targeted. They have not resulted in wholesale human domestication. Further, the constitutional provisions enacted in Ecuador and the declaration currently 
before the United Nations could similarly be implemented in a targeted or needs based fashion into domestic law. Lawmakers also have the freedom to expressly limit application to certain areas. This of course might raise other concerns and impact the effectiveness of rights as a tool for environmental protection. Certainly advocates of rights for nature will need to be conscious of the risks posed by rights proliferation both across and within nature.

Livingston's second concern to maintain 'natural relationships' has been echoed most visibly by communitarian writers who contend that social relationships ought to be based on sympathy and care. In a respectful and loving household few would deny a preference for this approach. The argument for recognising human rights becomes stronger in abusive households. Similarly, if a dog owner was cruel or neglectful few would deny the obligation of organisations such as the RSPCA to intervene to protect the animal. The point is that recognising the rights of nature does not mean that human beings must always interact or engage with nature or non-human animals in an artificial or political way. We do not ordinarily do this with other human beings. However, in some circumstances it may be appropriate to interact with nature with recognition of its rights and our corresponding duties toward it. This is most obvious in extractive economic relationships such as mining, logging and fisheries. In these relationships rights may occupy a fall back position when 'natural' relationships lead to exploitation and harm. Speaking with reference to marriage, Jeremy Waldron notes:

there is a need for an array of formal and legalistic rights and duties, not to constitute the affective bond, but to provide each person with secure knowledge of what she can count on in the unhappy event that there turns out to be no basis for her dealings with her erstwhile partner in the relationship. The importance of rights ought to be much easier to defend from this somewhat less inflated position. (629)

A similar position can be adopted with reference to nature. Rights ought not to constitute our bond, but in the context of extractive and exploitative industry we cannot rely on affection and care. In this instance, rights could provide a powerful device to regulate human behaviour and intervene when necessary for environmental protection. As Waldron notes, there is value in being 'realistic enough to notice the tragedy of a broken bond and ask "what happens next?"' (647).

\section{Individualism}

One final objection to extending rights to nature is that legal rights are excessively individualistic (Plumwood 152). Joseph Raz argues that there is a right if and only if some interest (i.e. aspect of well being or moral interest) of some entity capable of being a right holder is sufficient to ground a duty to 
care for and promote the interest in a significant way (183). Thus, that $x$ has a right means that some aspect of $x^{\prime} s$ wellbeing is a sufficient reason for holding some other person to be under a duty. Considered in the context of nature, legal rights are essentially claims, which place a duty on another individual or group of individuals. Logically speaking the individual claim comes first and the duty follows. The application of this concept to nature is potentially problematic. Indeed, it asks us to fragment an integrated system and impose an artificial system of competing interests. As Ted Benton notes, rights theory proceeds as if the moral status of nature 'were a function of the kinds of being they are, independently of the diverse relationships in which they stand to human moral agents and their social practices' (92). Arguably, this framework focuses on ranking species and systems and dissuades more complex thinking about the interdependent constitution of nature and concepts such as relationship.

This paper will not attempt to dissuade the reader about the individualistic nature of rights or the serious questions that arise in their implementation with nature. Instead, it will focus on a relevant branch of rights discourse, which seeks to shift the focus of rights from individuals, to relationships. ${ }^{12}$ The relational nature of rights was recognised by Wesley Newcomb Hohfeld in two historic law review articles in 1913 and 1917. Rights, according to Hohfeld, actually constitute jural relations. He identified four types of relationships, which he described in eight distinct concepts. These eight concepts can be grouped into four pairs of correlatives, which describe legal relationships from the standpoint of both the one who is entitled and others who are thereby obliged or vulnerable to the effects of the right. The point is that, at any time a right is conferred, it necessarily puts someone else at a disadvantage. The eight basic legal rights identified by Hohfeld are set out in Figure 1 below (Hohfeld, 'Fundamental Legal Conceptions' 714).

12 From the outset I wish to make clear that Nedelsky is referencing human relationships. In this section I am seeking to extend the term 'relationship' further to encompass nature. 


\begin{tabular}{|c|c|c|c|}
\hline Right & Privilege & Power & Immunity \\
\hline $\begin{array}{l}\text { Claims enforceable } \\
\text { by state power } \\
\text { that others act in a } \\
\text { certain manner in } \\
\text { relation to the right } \\
\text { holder. }\end{array}$ & $\begin{array}{l}\text { Permission to act (or } \\
\text { refrain from acting) } \\
\text { in a certain manner, } \\
\text { without being liable } \\
\text { for damages to } \\
\text { others and without } \\
\text { others being able to } \\
\text { summon state power } \\
\text { to prevent those } \\
\text { acts. }\end{array}$ & $\begin{array}{l}\text { State-enforced } \\
\text { abilities to change } \\
\text { legal entitlements } \\
\text { held by oneself or } \\
\text { others. }\end{array}$ & $\begin{array}{l}\text { Protections against } \\
\text { having one's } \\
\text { entitlement changed } \\
\text { by others. }\end{array}$ \\
\hline (Duty) & (No right) & (Liability) & (Disability) \\
\hline $\begin{array}{l}\text { The absence of } \\
\text { permission to act in } \\
\text { a certain manner. }\end{array}$ & $\begin{array}{l}\text { One does not } \\
\text { have the power to } \\
\text { summon the aid of } \\
\text { the state to alter the } \\
\text { behaviour of others. }\end{array}$ & $\begin{array}{l}\text { The absence of } \\
\text { immunity from } \\
\text { having entitlement } \\
\text { changed by others. }\end{array}$ & $\begin{array}{l}\text { The absence of } \\
\text { power to alter legal } \\
\text { entitlements. }\end{array}$ \\
\hline
\end{tabular}

Figure 1: Hohfeld's Analysis

In this box, every vertical represents a correlation and every diagonal an opposition. Thus, if a landowner has a right to a piece of land, non-owners have a duty to respect this right. Here the focus of the right is not individual entitlement, but on the surrounding relationship. Further, if nature is recognised as having the right to exist, a duty is placed against human beings who no longer have permission to act in a certain manner. Beyond this, it is difficult to see how nature can engage with the concept of rights. Indeed, in support of Rolston's critique, Hohfeld's table illustrates the conceptual difficulty of importing or recognising full legal rights in nature. It is clearly nonsense to speak of nature holding privileges, powers, immunities or the corresponding categories such as duties. Nature can only enter this framework as a 'right-holder'.

Contemporary writers such as Jennifer Nedelsky and Joseph William Singer have progressed the relational view of rights. Nedelsky, for example, argues that rights should not be viewed as clashing of individual interests or as absolute power within predefined spheres. Instead she situates rights within a broad web of relationships, limited by their impact on others ('Reconceiving Rights' 13). She notes, 'what rights in fact do and have always done is construct relationshipsof power, of responsibility, of trust and obligation' ('Reconceiving Rights' 13). From this perspective, rights create a setting in which individuals and communities live their lives and interact with others. This setting consists partly of rules requiring individuals to respect the legitimate interests of others. Other rules are designed to ensure that the comprehensive Earth community functions well. We should thus understand rights as socially constructed, involving not only relations between people, but also between people and things. While 
some might view relationships with nature as a limitation on human autonomy, Nedelsky points out that individuals achieve autonomy not in isolation, but by a combination of independence and dependence. She notes:

This approach shifts the focus from protection against others to structuring relationships so that they foster autonomy. Some of the most basic presuppositions about autonomy shift: dependence is no longer the antithesis of autonomy but a precondition in the relationships ... which provide the security, education, nurturing and support that make the development of autonomy possible ... Interdependence becomes the central fact of political life. ('Reconceiving Rights' 8; 'Reconceiving Autonomy' 7)

What difference would it make to focus on relationships rather than individual rights? The importance of this approach is highlighted in the case of conflict. Consider for example that the South Australian Government passed law which recognised that the River Murray and Lower Lakes had the right to a healthy flow of water. Plainly such a law would conflict with the pre-existing rights of landowners, farmers and towns to draw water to meet their own needs. On a purely individualistic account of rights, this dispute would focus on the adversarial clashing of interests and a legal hierarchy would be established to settle the dispute. Without wishing to simplify the matter, if instead we focus on relationships then both social and environmental contexts become relevant to resolving the dispute. A court could examine their respective needs and their specific relationship. From a conservation perspective, a good outcome would be that the irrigators' right to draw water would become encumbered. This does not remove the irrigators' right; it contextualises its use and requires careful consideration and knowledge of the needs of the river and the unique function it plays in the ecosystem. Water could be drawn to the extent that these vital functions are maintained. While expressed in different terms and not as strong, this relational view can be witnessed in the role performed by the MurrayDarling Basin Authority and the system of water allocations which irrigators are obliged to comply with. ${ }^{13}$

In this instance, the greatest consequence from recognising the rights of nature is that it contextualises and places limits on human property rights. It is implicit in this framework that property owners look to nature as the standard or measure for their action. Guided in this way, our law could promote greater ecological awareness and express a community's growing understanding of nature and its willingness to respect nature's limits.

13 See <http://www.mdba.gov.au>. 


\section{Conclusion: Should We Be Speaking of Rights?}

Arguably the most influential modern advocate for the rights of nature is the late Thomas Berry. ${ }^{14}$ Berry was the inspiration behind a growing movement in law called Earth Jurisprudence. ${ }^{15}$ Earth Jurisprudence has played a key role in the legal developments noted above. As a cultural historian, Berry approached the issue of legal development from a unique perspective. While most commentators focus on how law regulates and restricts human behaviour, Berry recognised that law plays a subtler role in shifting our perceptions and the way we view the world. Obvious examples include how the abolition of slavery, the universal recognition of human rights and the limited recognition of animal rights have expanded our field of moral concern. He hoped that expanding the circle of rights to include nature would play a similar function and that the law could play a role in cultural change.

Importantly, Berry was also keenly aware of the philosophical objections and wider literature on rights. However, he argued that it was the most effective and long-term method for slowing the current environmental crisis. 'You begin from where you are', he said, 'the language of rights answers the legal establishment on its own terms' (qtd in Cashford 1). Berry was also aware that legal concepts such as right are not static and can expand or change focus. His definition of rights was far broader than conventionally employed at law. Speaking at the inaugural conference on Earth Jurisprudence, he noted, '[w] hen we use the term "rights" we mean the freedom of humans to fulfil their duties, responsibilities and essential nature and by analogy, the principle that other natural entities are entitled to fulfil their role within the Earth Community' (qtd. in Cullinan, 'Wild Law' 108).

Berry is an important example for current advocates of environmental rights. In particular he took seriously and sought to integrate the dialogue and objections raised by other environmental philosophers into his own theory of rights. Further, he viewed rights as an interim tool and began the work of evolving the concept toward a less adversarial and universalistic concept. The challenge for the current movement is to continue this work, engage with the extensive literature on rights and communicate their ideas in a way that is meaningful for communities and lawmakers. From one perspective, this places an additional

14 In his final book, The Great Work: Our Way into the Future, Berry notes, 'every being has rights to be recognised and revered. Trees have tree rights, insects have insect rights, rivers have river rights, mountains have mountain rights. So too with the entire range of beings throughout the universe. All rights are limited and relative'. Berry's argument for rights is developed further in a paper called 'Legal Conditions for Earth Survival' in Berry, Evening Thoughts.

15 See St Thomas and Berry University, Center for Earth Jurisprudence: <http://www.earthjuris.org >; Earth Jurisprudence Resource Center: <www.earthjurisprudence.org>; Navdanya \& Earth Democracy: $<$ http://www.navdanya.org/> 
burden atop of an already difficult task. However, it is essential to creating intellectually sound law, which is robust, long-lived and achieves the desired objective of environmental sustainability.

Peter Burdon is a PhD student and sessional teacher at the University of Adelaide, School of Law. Correspondence can be sent to Peter Burdon, University of Adelaide, School of Law, Ligertwood Building, Adelaide, SA 5005 or peter.d.burdon@adelaide. edu.au

\section{Acknowledgements}

I would like to acknowledge the help of Shani Burdon, Dr Paul Babie and Associate Professor Alexander Reilly in the preparation of this article.

\section{Works Cited}

Benton, Ted. Natural Relations: Ecology, Animal Rights, and Social Justice. London: Verso, 1993.

Berry, Thomas. The Great Work: Our Way into the Future. New York: Bell Tower, 1999.

—. 'Legal Conditions for Earth Survival.' Evening Thoughts: Reflecting on Earth as Sacred Community. Ed. Mary-Evelyn Tucker. San Francisco: Sierra Club Books, 2006.

Brown, Lester. Plan 4:0 Mobilizing to Save Civilization. New York: W. W. Norton \& Company, 2009.

Cashford, Jules. 'A Dedication to Thomas Berry.' Wild Law: A Reader in Earth Jurisprudence. Ed. Peter Burdon. Adelaide: Wakefield Press, forthcoming 2010.

Cullinan, Cormac. Wild Law: A Manifesto for Earth Justice. Devon: Green Books, 2002.

-. 'A History of Wild Law.' Wild Law: A Reader in Earth Jurisprudence. Ed. Peter Burdon. Adelaide: Wakefield Press, forthcoming 2010.

Douglas, William. A Wilderness Bill of Rights. Boston: Little Brown and Company, 1965. 
Elder, P.S. 'Legal Rights for Nature: The Wrong Answer to the Right(s) Question.' Osgood Hall Law Journal 22 (1984): 281.

Feinberg, Joel. 'The Rights of Animals and Unborn Generations.' Philosophy and Environmental Crisis. Ed. William T Blackstone. Athens, Ga: U of Georgia P, 1974.

—. Rights, Justice and the Bounds of Liberty. New Jersey: Princeton, 1980.

Hohfeld, Wesley. 'Some Fundamental Legal Conceptions as Applied to Judicial Reasoning.' Yale Law Journal 23 (1913): 16.

—. 'Fundamental Legal Conceptions as Applied in Judicial Reasoning.' Yale Law Journal 26 (1917): 710.

Leopold, Aldo. A Sand County Almanac: With Essays On Conservation From Round River. New York: Ballantine Books, 1966.

Linzey, Thomas. 'Of Corporations, Law, and Democracy: Claiming the Rights of Communities and Nature.' Twenty-Fifth Annual E. F. Schumacher Lecture, Massachusetts, 2005. <http://www.smallisbeautiful.org/events/25th.html> Accessed 19 Jun. 2009.

- Be the Change: How to Get What You Want In Your Community. Utah: Gibbs Smith, 2009.

Livingston, John. Rogue Primate: An Exploration of Human Domestication. Toronto: Roberts Rinehart Publishers, 1994.

-. 'John Livingston.' Listening to the Land: Conversations about Nature, Culture and Eros. Ed. Derrick Jensen. Vermont: Chelsea Green, 2004.

Mayhew, Lucy. 'Rights of Nature.' Resurgence Magazine 253 (2009): 8-9.

Margil, Mari. 'Stories from the Environmental Frontier.' Wild Law: A Reader in Earth Jurisprudence. Ed. Peter Burdon. Adelaide: Wakefield Press, forthcoming 2010.

Naff, John. 'Rejoinder.' American Bar Association Journal 58 (1972): 727.

Nash, Roderick. The Rights of Nature: A History of Environmental Ethics. Wisconsin: U of Wisconsin P, 1989.

Nedelsky, Jennifer. 'Reconceiving Autonomy: Sources, Thoughts and Possibilities.' Yale Journal of Law and Feminism 1 (1989): 7.

- ' 'Reconceiving Rights as Relationship.' Review of Constitutional Studies 1.16 (1993): 16. 
People's Conference on Climate Change and Mother Earth Rights. 'Declaration of the Rights of Mother Earth.' < http://motherearthrights.org/2010/04/27/ world-peoples-conference-on-climate-change-and-the-rights-of-motherearth/>. Accessed 1 Apr. 2010.

Plumwood, Val. Feminism and the Mastery of Nature. London: Routledge, 1993.

- Environmental Culture: The Ecological Crisis of Reason. London: Routledge, 2002.

Raz, Joseph. The Morality of Freedom. Oxford: OUP, 1986.

Rolston, Holmes. 'Rights and Responsibilities on the Home Planet.' Yale Journal of International Law 18 (1993): 251.

Sagoff, Mark. 'On Preserving the Natural Environment.' Yale Law Journal 84 (1974): 221.

- 'Do Non-Native Species Threaten the Natural Environment.' Journal of Agricultural and Environmental Ethics 18 (2005): 215.

Singer, Joseph William. Entitlement: The Paradoxes of Property. New Haven: Yale UP, 2000.

Schlatter, Richard. Private Property: The History of an Idea. London: George, Allen \& Unwin, 1951.

Stone, Christopher D. 'Do Morals Matter? The Influence of Ethics on Courts and Congress in Shaping US Environmental Policies.' Environmental Law and Policy Journal 26 (2003-2004): 13.

- Earth and Other Ethics: The Case for Moral Pluralism. New York: Harper \& Row, 1985.

- Should Trees Have Standing: And Other Essays on Law, Morals and the Environment. New York: Oxford UP, 2010.

Waldron, Jeremy. 'When Justice Replaces Affection: The Need for Rights.' Harvard Journal of Law and Public Policy 11 (1988): 625. 